\title{
PENGARUH STRATEGI PEMBELAJARAN DAN MOTIVASI BELAJAR TERHADAP HASIL BELAJAR AKIDAH AKHLAK SISWA MIN SEI MATI MEDAN
}

\author{
Rini Sartika \\ Mahasiswa S2 FITK UIN SU Medan
}

\begin{abstract}
This study aims to find out and to stress: (1) the effect of the application of learning strategies on students' Akidah Akhlah learning outcomes, (2) the effect of learning motivation on student Akidah Akhlah learning outcomes, and (3) the interaction between learning strategies and learning motivation towards Akidah Akhlak learning outcomes. The population of this study was all students in class V MIN Sei Mati Medan consisting of 3 classes. Based on Cluster Random sampling techniques. The research instrument is a test used to obtain learning outcome data and questionnaires to obtain data on student learning motivation. The analysis technique is two-way Anova at significance $\alpha=0.05$ followed by the Scheffe test. The results showed: (1) the average learning outcomes of students taught with collaborative learning strategies $\bar{X}=28.15$ higher than the average learning outcomes of students taught with competitive learning strategies $\bar{X}=26.92$, with $\mathrm{F}_{\text {count }}=29.57>\mathrm{F}_{\text {table }}=3.968$, (2) the average learning outcomes of students with high learning motivation $\bar{X}=$ 29.93 higher than the learning outcomes of students with low learning motivation $\bar{X}=25.94$ with $\mathrm{F}_{\text {count }}=4.43>\mathrm{F}_{\text {table }}=3.968$, and (3) there is an interaction between learning strategies and learning motivation towards Akidah Akhlak learning outcomes with $\mathrm{F}_{\text {count }}=7.18>\mathrm{F}_{\text {table }}=3.968$.
\end{abstract}

\section{Kata Kunci: Strategy, Motivation and Learning Outcomes}

\section{PENDAHULUAN}

Pembelajaran di madrasah, terdapat banyak unsur yang saling berkaitan dan menentukan keberhasilan dalam proses pembelajaran. Unsur-unsur tersebut adalah: pendidik (guru), peserta didik (siswa), kurikulum, pengajaran, dan lingkungan. Siswa sebagai subjek dalam proses tersebut juga sangat berperan dalam keberhasilan kegiatan pembelajaran. Salah satu tugas pendidik atau guru adalah menciptakan suasana pembelajaran yang dapat membuat siswa untuk senantiasa belajar dengan baik dan bersemangat. Suasana pembelajaran yang demikian akan berdampak positif dalam pencapaian prestasi belajar yang optimal. 
Pembelajaran Akidah Akhlak pada prinsipnya bertujuan untuk meningkatkan keimanan, pemahaman, dan penghayatan nilai-nilai keagamaan (keislaman), serta pemahamannya. Sehingga kemudian diharapkan dapat menjadi muslim yang beriman dan bertaqwa kepada Allah SWT, serta berakhlaq mulia, dalam arti memiliki kesadaran moral yang tinggi dalam kehidupan pribadi dan masyarakat, serta dalam kehidupan berbangsa dan bernegara. Akidah Akhlak adalah pendidikan dengan menjadikan ajaran-ajaran agama (Islam) sebagai fokus pembelajaran. Atau sebagai sebuah upaya berupa bimbingan dan asuhan terhadap anak didik dan mengarahkannya pada penghayatan dan pengamalan ajaran dan nilai-nilai keislaman dalam kehidupan sehari-hari. Islam sebagai agama memiliki peranan penting dalam memberikan pedoman dan petunjuk bagaimana seharusnya menjalani kehidupan bermasyarakat dan bernegara secara beradab.

Penerapan strategi yang tepat maka materi ajar dalam Akidah Akhlak dapat diserap oleh anak didik dengan sebaik-baiknya. Strategi yang tepat akan menentukan efektifitas dan efisiensi pembelajaran. Sebagai seorang guru pendidik agama Islam maka perlu mengetahui strategi-strategi dalam pembelajaran Akidah Akhlak. Dengan mengetahui strategi-strategi tersebut maka guru diharapkan mampu menyampaikan materi-materi ajaran agama Islam dengan berbagai variasi sehingga tujuan pendidikan agama Islam dapat tercapai dengan lebih mudah.

Selanjutnya karakteristik siswa yang merupakan faktor yang harus diperhatikan guru yang meliputi motivasi, minat, kemampuan awal, gaya belajar dan sebagainya. Peneliti memfokus pada karakteristik siswa pada aspek motivasi belajar. Motivasi belajar siswa sebagai faktor internal sangat perlu diperhatikan dan dipertimbangkan, karena ini akan memengaruhi hasil belajar Akidah Akhlak, hal ini didukung hasil penelitian Warti (2016) bahwa motivasi belajar siswa berpengaruh positif dengan hasil belajar. Motivasi yang dimaksud adalah motivasi untuk belajar, yakni motivasi yang dapat meningkatkan minat siswa untuk belajar dan meningkatkan prestasi. Apabila siswa memiliki motivasi belajar yang tinggi maka siswa akan lebih berhasil menguasai materi ajar Akidah Akhlak. Strategi pembelajaran yang berbeda akan berpengaruh terhadap proses belajar dan hasil belajar siswa, sedangkan motivasi belajar dalam diri siswa akan menggerakkan perilaku belajar.

Pemilihan strategi pembelajaran yang tepat dibutuhkan dan harus disesuaikan dengan motivasi belajar siswa, karena mempelajari materi ajar Akidah Akhlak yang cukup padat dituntut kemandirian belajar siswa 
dalam mencari sumber-sumber lain. Oleh karena itu, kemandirian belajar siswa adalah salah satu komponen yang harus diperhatikan dengan seksama oleh guru dalam mengidentifikasi kemampuan yang dimiliki peserta didiknya yang akan membantu dalam menentukan materi, strategi, metode dan media yang tepat untuk digunakan. Hal ini perlu dilakukan agar pembelajaran yang disampaikan dapat menarik perhatian siswa dan setiap detik yang berlangsung dalam kegiatan pembelajaran yang dilakukan akan bermakna dan tidak membosankan bagi siswa.

\section{KAJIAN TEORETIS}

\section{Hasil Belajar}

Siswa yang belajar akan mengalami perubahan prilaku berupa pengetahuan, sikap dan ketrampilan. Pengetahuan menunjuk pada informasi yang tersimpan dalam pikiran, sikap adalah kemampuan seseorang menerima atau menolak obyek berdasarkan penilaian terhadap obyek tersebut, sedangkan ketrampilan adalah suatu tindakan atau tingkah laku yang mampu diperlihatkan siswa sebagai tanda bahwa siswa tersebut telah belajar. Selanjutnya Dimyati dan Mudjiono (1999:3) menjelaskan hasil belajar merupakan hasil dari suatu interaksi tindak belajar dan tindak mengajar.

Hasil belajar didapat dari penilaian yang tidak dapat dipisahkan dari keseluruhan penyelenggaraan pendidikan. Asumsi dasarnya ialah proses pengajaran yang optimal memungkinkan hasil belajar yang optimal pula. Makin besar usaha untuk menciptakan kondisi proses pengajaran, makin tinggi pula hasil atau produk dari pengajaran itu. Djamarah dan Zain (2002:59) menjelaskan bahwa hasil belajar adalah penguasaan siswa terhadap bahan/materi pelajaran yang telah guru berikan ketika proses mengajar berlangsung.

Gagne dan Briggs dalam Sudjana (2002:45) mengemukakan bahwa hasil belajar dapat dikelompokkan ke dalam lima kategori, yaitu keterampilan intelektual, strategi kognitif, informasi verbal, kemampuan motorik dan sikap. dalam hal ini hasil belajar diperoleh dalam bentuk pengetahuan dan keterampilan. Rohani dan Ahmadi (2005:169) mengatakan bahwa penilaian hasil belajar bertujuan melihat kemajuan belajar siswa dalam hal penguasaan materi pengajaran yang telah dipelajarinya sesuai dengan tujuan-tujuan yang telah ditetapkan. Tujuan merupakan sasaran atau obyek yang akan dicapai.

Sasaran atau obyek evaluasi hasil belajar adalah perubahan tingkah laku yang mencakup bidang kognitif, afektif dan psikomotor secara 
seimbang. Aspek-aspek tersebut sebaiknya dapat diungkapkan melalui penilaian tersebut. Dengan demikian dapat diketahui tingkah laku mana yang sudah dikuasai siswa dan mana tingkah laku yang belum dikuasai siswa. Hasil belajar merupakan perolehan prestasi atau hasil yang dicapai secara maksimal oleh siswa. Belajar merupakan proses atau kegiatan yang dijalani secara sadar untuk mendapatkan perubahan, baik dalam bentuk pengetahuan, ketrampilan ataupun sikap. Hasil belajar merupakan prestasi yang dicapai siswa oleh karena adanya usaha sadar yang dilakukan siswa untuk mendapatkan perubahan, baik dalam bentuk pengetahuan, ketrampilan dan sikap.

Pembelajaran Akidah Akhlak adalah bidang studi yang diberikan di madrasah ibtidaiyah dengan maksud untuk memberikan seperangkat pengetahuan, bentuk-bentuk ketrampilan dan penanaman sikap dan nilai dalam konteks disiplin ilmu Akidah Akhlak. Pembelajaran Akidah Akhlak diberikan dengan mengikuti tuntunan bahwa agama diajarkan kepada manusia dengan visi untuk mewujudkan manusia yang bertakwa kepada Allah SWT dan berakhlak mulia, serta bertujuan untuk menghasilkan manusia yang jujur, adil, berbudi pekerti, etis, saling menghargai, disiplin, harmonis dan produktif, baik personal maupun sosial.

Berkaitan dengan hasil belajar, maka hasil belajar Akidah Akhlak merupakan gambaran dan tingkat kesanggupan kognitif yang diperoleh dalam bentuk pengetahuan dan ketrampilan. Dalam bentuk pengetahuan meliputi fakta, konsep, prosedur dan prinsip. Fakta, konsep, prosedur dan prinsip merupakan bidang kajian Akidah Akhlak. Fakta, konsep, prosedur dan prinsip dalam materi Akidah Akhlak akan berarti atau bermakna bagi siswa apabila dihubungkan dengan fakta yang ada di dalam kehidupan sehari-hari siswa. Sedangkan bentuk keterampilan yang menggambarkan tingkat kesanggupan kognitif, yaitu ketrampilan siswa menggunakan pikiran, guna menghadapi sesuatu peristiwa seperti pengambilan keputusan dan pemecahan masalah.

Berdasarkan deskripsi teoritis hasil belajar di atas, maka yang dimaksudkan dengan hasil belajar Akidah Akhlak dalam penelitian ini adalah data hasil belajar yang dapat diperlihatkan peserta didik melalui proses pengujian yang sistematis dengan mengerjakan soal-soal tes materi ajar Akidah Akhlak untuk kelas V pada ranah kognitif. 


\section{Strategi Pembelajaran}

Strategi pembelajaran diartikan kegiatan baik prosedur, langkah maupun metode dan teknik yang dipilih agar dapat memberikan kemudahan, fasilitas dan atau bantuan lain kepada siswa dalam mencapai tujuan-tujuan instruksional. Strategi pembelajaran juga dipakai untuk mencakup berbagai aspek dalam mengorganisasikan informasi serta cara menyajikannya. Pemilihan media, pengurutan materi, dan pemotongan materi tercakup dalam ruang lingkup strategi pembelajaran.

Seels dan Richey (1994:24) menjelaskan bahwa strategi pembelajaran adalah spesifikasi untuk memilih dan mengurutkan kejadian dan aktivitas pembelajaran. Aktivitas pembelajaran meliputi penyajian materi, pemberian contoh, pemberian latihan, serta pemberian umpan balik. Agar tujuan pembelajaran tercapai secara optimum maka semua aktivitas harus diatur dengan mempertimbangkan karakteristik peserta didik, media, dan situasi di sekitar proses pembelajaran.

Gagne dan Briggs (1979:81) mengatakan bahwa sistem instruksional (pembelajaran) adalah suatu set peristiwa yang mempengaruhi siswa sehingga terjadi proses belajar. Suatu set peristiwa itu mungkin dilakukan oleh pengajar sehingga disebut pembelajaran, mungkin juga dilakukan oleh siswa sendiri dengan menggunakan buku, gambar, program televisi atau kombinasi berbagai media, baik oleh pengajar maupun oleh siswa sendiri, kegiatan itu haruslah terencana secara sistematik untuk dapat disebut kegiatan kegiatan pembelajaran.

Dick dan Carey (2005:65) mengatakan bahwa strategi pembelajaran memuat lima komponen utama yaitu: (1) aktivitas pembelajaran pendahuluan, (2) penyampaian informasi, (3) partisipasi siswa, (4) tes, dan (5) kegiatan lanjutan. Suparman (2012:43) mendefinisikan strategi pembelajaran sebagai perpaduan dari (1) urutan kegiatan instruksional, (2) metode instruksional, (3) media instruksional, dan (4) waktu yang digunakan dalam proses pembelajaran. Kedua definisi di atas pada prinsipnya lebih menekankan pada aspek komponen dan prosedur pembelajaran.

\section{a. Strategi Pembelajaran Kolaboratif}

Jonassen (1996:78) mendefinsikan pembelajaran kolaboratif adalah suatu pembelajaran kelompok kecil di mana para siswa bekerja bersama-sama untuk memaksimalkan hasil belajarnya sendiri dan hasil belajar anggota kelompok lainnya. Proses belajar secara kolaboratif bukan sekedar bekerja sama dalam suatu kelompok tetapi penekanannya lebih 
kepada suatu proses pembelajaran yang melibatkan proses komunikasi secara utuh dan adil di dalam kelas.

Gunawan (2004:187) menyatakan ada lima elemen penting yang harus ada dalam pembelajaran kolaboratif yaitu: (1) Interpendensi yang positif yaitu (perasaan kebersamaan, (2) Interaksi face to face atau tatap muka yang saling mendukung (saling membantu, saling menghargai, memberi selamat dan merayakan sukses bersama, (3) Tanggung jawab individu dan kelompok keberhasilan pembelajaran, (4) Kemampuan komunikasi antarpribadi dan komunikasi dalam suatu kelompok kecil (komunikasi, rasa percaya, kepemimpinan, pembuatan keputusan dan manajemen serta resolusi konflik), dan (5) Pemrosesan secara kelompok (melakukan refleksi terhadap fungsi dan kemampuan mereka bekerja sama sebagai suatu kelompok dan bagaimana untuk mampu berprestasi lebih baik lagi).

Davis (1993:89) menyatakan bahwa ciri utama dari pembelajaran kolaboratif adalah: (1) Siswa bekerja dalam tim untuk menguasai materi pelajaran, (2) Tim atau kelompok dibentuk bervariasi dari siswa yang memiliki kinerja akademis tinggi, sedang, dan rendah, (3) Tim terdiri dari anggota yang bervariasi dari segi jenis kelamin, dan ras, dan (4) Sistem ganjaran berorientasi pada kelompok, bukan individu.

Hill dan Hill (1996:78) bahwa ada dua unsur penting yang selalu ada dalam kegiatan kolaboratif yakni kesamaan tujuan dan saling ketergantungan (interdependensi) yang positif.. Johnson dan Johnson (1997:89) mengemukakan beberapa unsur dasar pembelajaran kolaboratif yakni: (1) Saling ketergantungan yang positif di mana keberhasilan kelompok ditentukan oleh keberhasilan dari anggota-anggota kelompok yang berinteraksi secara positif, (2) Adanya interaksi langsung di mana para anggota kelompok bertemu secara langsung dalam memecahkan masalah atau menyelesaikan tugas-tugasnya, (3) Akuntabilitas individual dan tanggung jawab pribadi, di mana masing-masing individu memegang peranan masing-masing yang sangat vital bagi keberhasilan kelompok seluruhnya. Oleh karena itu akuntabilitas atau tanggung jawab individu sangat ditekankan, (4) Keterampilan kolaboratif, yakni keterampilanketerampilan yang berhubungan dengan kepemimpinan, komunikasi, pembuatan keputusan, pembentukan kepercayaan, dan manajemen konflik, (5) Pemrosesan kelom-pok di mana kelompok bersama-sama membahas bagaimana bekerja dan berinteraksi secara efektif untuk mencapai tujuan bersama. 
Gunawan (2004:190) menjelaskan langkah-langkah pembelajaran kolaboratif yaitu: (1) Inisiasi dan apersepsi yang bertujuan mengundang dan memusatkan perhatian siswa, (2) Pembentukan kelompok-kelompok belajar, (3) Penyelesaian tugas dalam kelompok, dan (4) Paparan atau presentase tugas.

\section{b. Strategi Pembelajaran Kompetitif}

Strategi pembelajaran kompetitif merupakan suatu jenis strategi pembelajaran di mana para siswa belajar dan menyelesikan tugastugasnya secara individual atau mandiri. Jenis pembelajaran ini sebenarnya merupakan jenis pembelajaran yang biasa dilakukan dalam guru selama ini. Dikatakan kompetitif karena penekanannya pada sistem ganjaran yang bersifat individual. Latar pembelajarannya adalah kelas dan para siswa diberi arahan, penjelasan dan penugasan oleh guru kemudian mereka mengerjakannya secara sendiri-sendiri tanpa ada interaksi langsung dengan teman-teman sekelasnya.

Secara psikologis pembelajaran kompetetif berlangsung di dalam kelas merupakan refleksi dari prinsip individualitas. Rohani dan Ahmadi (2005:81) menjelaskan prinsip individualitas dalam konteks pembelajaran sebagai berikut: setiap individu mempunyai sifat-sifat, bakat dan kemampuan yang berbeda, setiap individu mempunyai cara belajar menurut caranya sendiri, setiap individu mempunyai minat khusus yang berbeda, setiap individu mempunyaia latar belakang (keluarga) yang berbeda, setiap individu membutuhkan bimbingan khusus dalam menerima pelajaran yang diajarkan guru sesuai dengan perbedaan individual dan setiap individu mempunyai irama pertumbuhan dan perkembangan yang berbda-beda.

Nasution (2000:87) menjelaskan cara untuk menyesuaikan pembelajaran individual dimana nuansa kompetitif berlangsung yaitu, siswa menerima tugas yang diselesaikan menurut kecepatan masingmasing, siswa diberi tugas tambahan, siswa mengerjakan sesuatu sesuai dengan minat dan kesanggupannya

Tujuan pembelajaran kompetitif sebagaimana diungkapkan Johnson dan Johnson (1996:120) adalah memaksimalkan kinerja akademis masingmasing siswa demi mencapai prestasi tertinggi yang mungkin hanya bisa dicapai oleh satu atau beberapa orang siswa saja. Schmuck \& Schmuck (2000:78) menyatakan untuk mencapai tujuan itu siswa dipacu semangatnya untuk berkompetisi dengan asumsi bahwa teman-teman kelasnya adalah saingan yang harus dikalahkan. Kesempatan untuk 
berkompetisi secara individual dapat memberikan insentif dan kegairahan bagi kegiatan-kegiatan di kelas, apakah kompetisi untuk mendapatkan hadiah dan pujian ataukah untuk kepuasan semata.

Berkaitan dengan penerapan strategi kompetitif, Johnson dan Johnson (1997:96) menyatakan bahwa penerapan strategi kompetitif di sekolah didasarkan atas beberapa asumsi yang menyerupai mitos yakni: (1) Masyarakat kita saat ini hidup dalam situasi yang sangat kompetitif dan para siswa harus dididik untuk bersaing sehingga mereka dapat bertahan hidup dalam situasi yang penuh persaingan, (2) Prestasi, kinerja yang luar biasa, munculnya pemimpin besar, dorongan, ambisi, dan motivasi sangat tergantung pada seberapa jauh seseorang bersaing dengan orang lain, (3) Kompetisi dapat membangun karakter yang tangguh dan memperkuat hidup dalam dunia nyata, (4) Siswa lebih suka dengan suasana kompetisi, dan (5) Kompetisi dapat meningkatkan kepercayaan diri dan harga diri.

Johnson dan Johnson (1997:127) menjelaskan langkah-langkah pembelajaran kolaboratif yaitu: (1) Penyampaian materi ajar, (2) Pemberian tugas individual, (3) Penyelesaian tugas, (4) Pemeriksaan hasil tugas.

\section{Motivasi Belajar.}

Motivasi berasal dari kata motif (motive) yang artinya daya penggerak yang telah aktif. Purwanto (2000:67) menyatakan bahwa motif adalah sesuatu pernyataan yang konfleks di dalam suatu organisme yang mengarahkan tingkah laku dan perbuatan sesuatu organisme yang mengarahkan ke suatu tujuan atau perangsang. Proses pemeranan motif atau menggiatkan motif disebut motivasi. Perilaku seseorang pada dasarnya ditentukan oleh keinginannya untuk mencapai beberapa tujuan. Keinginan ini akan mendorong seseorang berperilaku dan dorongan inilah yang disebut dengan motivasi (Smittle, 2003:9).

Motivasi merupakan usaha-usaha untuk menyediakan kondisi sehingga invidu itu mau atau ingin melakukannya. Di dalam motivasi sebagai kekuatan dinamik yang mendorong seseorang melakukan sesuatu karena di dalam motivasi itu juga tersimpan berbagai kemampuan untuk melakukan sesuatu. Motivasi sebagai keadaan dalam diri pribadi seseorang yang mendorong keinginan individu untuk melakukan kegiatan-kegiatan tertentu guna mencapai tujuan (Smittle, 2003:11).

Motivasi sebagai faktor inner (batin) berfungsi menimbulkan, mendasari, mengarahkan perbuatan seseorang. Demikian pula dalam 
bekerja, motivasi dapat membangkitkan dorongan seseorang untuk sungguh-sungguh melakukan kegiatan yang menjadi tugas-tugasnya. Motivasi dapat membuat seseorang gigih melakukan berbagai aktivitasnya. Seorang guru harus dapat membangkitkan motivasi sebagai perangsang yang membangkitkan gairah siswa untuk belajar.

Menurut Davies (2001:56), menyatakan bahwa istilah motivasi berasal dari bahasa Latin, yaitu movere yang berarti menggerakkan. Berdasarkan kata tersebut, selanjutnya dapat dikembangkan lebih banyak definisi atau pengertian tentang motivasi. Istilah motivasi berasal dari kata motif yang dapat diartikan sebagai kekuatan yang terdapat dalam diri individu, yang menyebabkan individu tersebut bertindak atau berbuat.

Motivasi merupakan suatu kekuatan (power), tenaga (forces), daya (energy), atau suatu keadaan yang kompleks (a complex state) dan kesiapsediaan (preparatory set) dalam diri individu (organisme) untuk bergerak (to move, motion, motive) kearah tujuan tertentu, baik disadari maupun tidak disadari (Kurniadin dan Machali, 2012:331-332).

Motivasi juga dapat dikatakan sebagai perbedaan antara dapat melaksanakan dan mau melaksanakan. Motivasi lebih dekat pada mau melaksanakan tugas untuk mencapai tujuan. Motivasi adalah kekuatan, baik dari dalam maupun luar yang mendorong seseorang untuk mencapai tujuan tertentu yang telah ditetapkan sebelumnya. Dengan kata lain, motivasi dapat diartikan sebagai dorongan mental terhadap perorangan atau orang-orang sebagai anggota masyarakat. Motivasi dapat juga diartikan sebagai proses untuk mencoba mempengaruhi orang atau orang-orang yang terlibat dalam proses pembelajaran agar melakukan belajar sesuai dengan tujuan tertentu yang diinginkan.

Motivasi merupakan salah satu komponen terpenting dalam mencapai hasil pembelajaran dalam bidang studi Akidah Akhlak. Apabila dalam diri siswa terdapat keinginan untuk belajar Akidah Akhlak, hal ini berarti dalam dirinya muncul kesediaan untuk mengerahkan seluruh upaya untuk mempelajarinya secara sungguh-sungguh.

Hamalik (2003:158), menyatakan ada dua prinsip yang dapat digunakan untuk meninjau motivasi ialah: (1) Motivasi dipandang sebagai suatu proses. Pengetahuan tentang proses ini akan membantu menjelaskan kelakuan yang diamati dan untuk memperkirakan kelakuankelakuan lain pada seseorang, dan (2) Menentukan karakter dari proses ini dengan melihat petunjuk-petunjuk dari tingkah lakunya. Apakah 
petunjuk-petunjuk dapat dipercaya, dapat dilihat kegunaannya dalam memperkirakan dan menjelaskan tingkahlaku lainnya.

Motivasi merupakan pendorong untuk keberhasilan seseorang. Slavin (2004:167), menyatakan bahwa kerja keras yang muncul dari dalam diri yang menggambarkan keinginan, kemauan dan dorongan. Berdasarkan perspektif manajemen orang yang termotivasi dapat digambarkan sebagai berikut: (1) Orangnya bekerja keras, (2) Secara terus menerus bekerja keras dan (3) Perilakunya mengarah langsung ke tujuan utama.

Motivasi mendorong timbulnya tingkah laku dan mempengaruhi serta mengubah tingkah laku. Oleh sebab itu Hamalik (2004:161) menyatakan bahwa fungsi motivasi adalah: (1) Mendorong timbulnya tingkah laku atau perbuatan. Tanpa motivasi tidak akan timbul suatu perbuatan, misalnya belajar, (2) Motivasi berfungsi sebagai pengarah, artinya mengarahkan perbuatan untuk mencapai tujuan yang diinginkan, dan (3) Motivasi berfungsi sebagai penggerak, artinya menggerakkan tingkah laku seseorang. Besar kecilnya motivasi ini akan memengaruhi cepat lambatnya suatu pekerjaan/tugas dapat diselesaikan dengan baik. Sementara itu Uno (2016) menjelaskan motivasi terkait dengan: (1) harapan berhasil dalam belajar, (2) semangat berprestasi, dan (3) memiliki keinginan belajar yang tinggi.

\section{METODOLOGI PENELITIAN}

Penelitian ini dilaksanakan di Madrasah Ibtidaiyah Negeri (MIN) Sei Mati Medan. Metode yang dipergunakan dalam penelitian ini adalah metode quasi-eksperimen. Metode ini dipilih karena kelas yang dipakai untuk perlakuan baik untuk kelas pembelajaran dengan kolaboratif maupun kelas pembelajaran kompetitif merupakan kelas yang sudah terbentuk sebelumnya dan karakteristik siswa yang dikontrol adalah motivasi belajar. Desain penelitian yang digunakan dalam penelitian ini adalah faktorial $2 \times 2$. Populasi penelitian adalah seluruh siswa kelas $\mathrm{V}$ MIN Sei Mati Medan yang terdiri dari 3 kelas. Teknik penentuan sampel digunakan cluster random sampling. Teknik ini dipilih karena yang disampling dari populasi adalah jumlah kelas (sebanyak 3 kelas) bukan jumlah siswa dalam populasi. Instrumen dan teknik pengumpulan data dalam penelitian yaitu tes dan angket. Tes dilakukan untuk mengumpulkan data hasil belajar Akidah Akhlak sedangkan angket untuk menjaring data motivasi belajar. Pengujian hipotesis dilakukan dengan teknik analisis varians (ANAVA) dua jalur. 


\section{HASIL PENELITIAN}

Hasil penelitian menunjukkan: (1) hasil belajar Akidah Akhlak siswa MIN Sei Mati Medan yang diajar dengan strategi pembelajaran kolaboratif diperoleh harga mean $\bar{X}=28$; modus $=29,76$; median $=28,5$; varians $=16,52$; simpangan baku $=4,06$; skor tertinggi $=36$; dan skor terendah $=20$, (2) hasil belajar Akidah Akhlak siswa MIN Sei Mati Medan yang diajar dengan strategi pembelajaran kompetitif diperoleh harga rata-rata mean $\bar{X}=26,92 ;$ modus $=26,3 ;$ median $=26,81 ;$ varians $=$ 15,02; simpangan baku =3,87; skor tertinggi $=34$; dan skor terendah $=19$, (3) hasil belajar Akidah Akhlak siswa MIN Sei Mati Medan dengan motivasi belajar tinggi yang diajar dengan strategi pembelajaran kolaboratif dan strategi pembelajaran kompetitif diperoleh nilai mean $\bar{X}$ = 29,93; modus $=30,15 ;$ median $=30$; varians $=10,15 ;$ simpangan baku = 3,18; skor tertinggi = 36; dan skor terendah $=23$, (4) hasil belajar Akidah Akhlak siswa MIN Sei Mati Medan dengan motivasi belajar rendah diperoleh harga mean $(\bar{X})=26$; modus $=25,73$; median $=25,82$; varians $=$ 13,02; simpangan baku $=3,60$; skor tertinggi $=34$; dan skor terendah $=19$, (5) hasil belajar Akidah Akhlak siswa MIN Sei Mati Medan yang diajar dengan strategi pembelajaran kolaboratif dan motivasi belajar tinggi diperoleh harga mean $(\bar{X})=32,36$; modus $=31,5$; median $=32,25$; varians $=6,55$; simpangan baku = 2,55; skor tertinggi $=36$; dan skor terendah $=28$, (6) hasil belajar Akidah Akhlak siswa MIN Sei Mati Medan yang diajar dengan strategi pembelajaran kolaboratif dan motivasi belajar rendah diperoleh harga mean $(\bar{X})=26$; modus $=25,5$; median $=25,66$; varians $=$ 8,02; simpangan baku $=2,83$; skor tertinggi $=31$; dan skor terendah $=20$, (7) hasil belajar Akidah Akhlak siswa MIN Sei Mati Medan yang diajar dengan strategi pembelajaran kompetitif dan motivasi belajar tinggi diperoleh harga mean $(\bar{X})=28$; modus $=28,5$; median $=28,25$; varians $=$ 8,47; simpangan baku $=2,91$; skor tertinggi $=34$; dan skor terendah $=23$, dan (8) hasil belajar Akidah Akhlak siswa MIN Sei Mati Medan yang diajar dengan strategi pembelajaran kompetitif dan motivasi belajar rendah diperoleh harga mean $(\bar{X})=26,04$; modus $=25,63$; median $=$ 25,$79 ;$ varians $=16,75 ;$ simpangan baku $=4,09$; skor tertinggi $=34$; dan skor terendah $=19$.

Pengujian hipotesis pertama yaitu hasil belajar Akidah Akhlak siswa MIN Sei Mati Medan yang diajar dengan strategi pembelajaran kolaboratif lebih tinggi daripada hasil belajar Akidah Akhlak siswa yang diajar dengan strategi pembelajaran kompetitif terbukti secara empirik. 
Hal ini berdasarkan perhitungan anava faktorial $2 \times 2$ diperoleh $\mathrm{F}_{\text {hitung }}=$ 29,57 sedangkan nilai $F_{\text {tabel }}=3,96$ untuk dk $(1,76)$ dan taraf nyata $\alpha=0,05$. ternyata nilai $\mathrm{F}_{\text {hitung }}=29,57>\mathrm{F}_{\text {tabel }}=3,96$ sehingga pengujian hipotesis menolak Ho.

Pengujian hipotesis kedua yaitu hasil belajar Akidah Akhlak siswa MIN Sei Mati Medan dengan motivasi belajar tinggi lebih tinggi dari pada hasil belajar Akidah Akhlak siswa dengan motivasi belajar rendah terbukti secara empirik. Hal ini berdasarkan perhitungan anava faktorial 2 $x 2$ diperoleh $F_{\text {hitung }}=4,43$ sedangkan nilai $F_{\text {tabel }}=3,96$ untuk dk $(1,76)$ dan taraf nyata $\alpha=0,05$. Ternyata nilai $F_{\text {hitung }}=4,43>F_{\text {tabel }}=3,96$ sehingga pengujian hipotesis menolak Ho.

Pengujian hipotesis ketiga yaitu terdapat interaksi antara strategi pembelajaran dan motivasi belajar dalam memberikan pengaruh terhadap hasil belajar Akidah Akhlak siswa terbukti secara empirik. Hal ini berdasarkan perhitungan anava faktorial $2 \times 2$ diperoleh $F_{\text {hitung }}=7,18$, sedangkan nilai $F_{\text {tabel }}=3,96$ untuk dk $(1,76)$ dan taraf nyata $\alpha=0,05$.

\section{PEMBAHASAN}

Hasil perhitungan statistik di atas, maka terlihat secara keseluruhan rata-rata hasil belajar Akidah Akhlak siswa MIN Sei Mati Medan yang diajar dengan strategi pembelajaran kolaboratif $(\bar{X}$ 28,15) lebih tinggi daripada rata-rata hasil belajar Akidah Akhlak siswa MIN Sei Mati Medan yang diajar dengan strategi pembelajaran kompetitif $(\bar{X}$ 26,92). Hal ini menunjukkan bahwa strategi pembelajaran kolaboratif terbukti efektif dapat meningkatkan hasil belajar Akidah Akhlak siswa MIN Sei Mati Medan secara keseluruhan baik untuk kelompok siswa dengan motivasi belajar tinggi maupun motivasi belajar rendah. Dari hasil temuan ini menunjukkan bahwa untuk mengajarkan materi Akidah Akhlak lebih efektif menggunakan strategi pembelajaran kolaboratif daripada dengan strategi pembelajaran kompetitif.

Strategi pembelajaran kolaboratif adalah sebuah strategi dalam pembelajaran berupa kelompok belajar yang saling bekerjasama. Oleh karena itu dalam pembelajaran kolaboratif terjadi interaksi, kerjasama dan saling membutuhkan di antara anggota-anggota kelompok belajar tersebut. Ukuran keberhasilan ditentukan berdasarkan sejauh mana kelompok belajar mencapai sasaran. Dalam kegiatan ini, kerjasama, tanggung jawab pribadi dan interaksi saling mendukung sangatlah 
diperlukan sebab keberhasilan kelompok ditentukan oleh keberhasilan dari individu-individu anggota yang terlibat di dalamnya.

Sementara itu strategi pembelajaran kompetitif sangat menekankan usaha pribadi untuk mencapai tujuan-tujuan yang telah ditetapkan. Interaksi antar sesama teman sangat kurang dan masing-masing individu berorientasi pada pencapaian hasil yang maksimal. Sistem penilaian dan ganjaran menjadi acuan untuk menentukan menang kalahnya seseorang dalam mencapai target yang ditetapkan.

Jika diperhatikan lebih lanjut bahwa dalam strategi pembelajaran kolaboratif rata-rata hasil belajar Akidah Akhlak siswa MIN Sei Mati Medan dengan motivasi belajar tinggi $(\bar{X}=32,36)$ lebih baik daripada hasil belajar Akidah Akhlak siswa MIN Sei Mati Medan dengan motivasi belajar rendah $(\bar{X}=25,84)$. Sedangkan pada strategi pembelajaran kompetitif, rata-rata hasil belajar Akidah Akhlak siswa MIN Sei Mati Medan dengan motivasi belajar tinggi $(\bar{X}=28,11)$ lebih baik daripada hasil belajar Akidah Akhlak siswa MIN Sei Mati Medan dengan motivasi belajar rendah $(\bar{X}=26,04)$.

Hal ini menunjukkan bahwa motivasi belajar cukup signifikan untuk membedakan hasil belajar siswa, di mana hasil belajar siswa dengan motivasi belajar tinggi baik yang diajar dengan strategi pembelajaran kolaboratif maupun strategi pembelajaran kompetitif lebih baik daripada hasil belajar siswa dengan motivasi belajar rendah. Peran motivasi dengan keberhasilan siswa MIN Sei Mati Medan dalam belajar sangat erat dan tidak bisa dipisahkan. Semakin tinggi motivasi belajar seorang siswa maka akan semakin besar pula upaya yang ia lakukan untuk mencapai keberhasilan belajarnya.

\section{SIMPULAN}

Simpulan hasil penelitian sebagai berikut: (1) rata-rata hasil belajar Akidah Akhlak siswa MIN Sei Mati Medan yang diajar dengan strategi pembelajaran kolaboratif lebih tinggi daripada rata-rata hasil belajar Akidah Akhlak siswa MIN Sei Mati Medan yang diajar dengan strategi pembelajaran kompetitif, Selanjutnya berdasarkan hasil pengujian statistik diperoleh $F_{\text {hitung }}=29,57$ sedangkan nilai $F_{\text {tabel }}=3,96$ untuk dk $(1,76)$ dan taraf nyata $\alpha=0,05$. ternyata nilai $F_{\text {hitung }}=29,57>F_{\text {tabel }}=3,96$. Dengan demikian strategi pembelajaran kolaboratif lebih efektif diterapkan dalam pembelajaran Akidah Akhlak guna meningkatkan hasil belajar Akidah Akhlak siswa, (2) rata-rata hasil belajar Akidah Akhlak siswa MIN Sei 
Mati Medan dengan motivasi belajar tinggi lebih tinggi dibandingkan dengan rata-rata hasil belajar Akidah Akhlak siswa MIN Sei Mati Medan dengan motivasi belajar rendah. Selanjutnya berdasarkan hasil pengujian statistik diperoleh diperoleh $F_{\text {hitung }}=4,43$ sedangkan nilai $F_{\text {tabel }}=3,96$ untuk dk $(1,76)$ dan taraf nyata $\alpha=0,05$. Ternyata nilai $F_{\text {hitung }}=4,43>$ $\mathrm{F}_{\text {tabel }}=3,96$, dan (3) Terdapat interaksi antara strategi pembelajaran dengan motivasi belajar, di mana siswa dengan motivasi belajar tinggi lebih tepat diajar menggunakan strategi pembelajaran kolaboratif, sedangkan siswa dengan motivasi belajar rendah lebih tepat diajar dengan strategi pembelajaran kompetitif. Hal terbukti melalui pengujian statistik diperoleh diperoleh $F_{\text {hitung }}=7,18$, sedangkan nilai $F_{\text {tabel }}=3,96$ untuk dk $(1,76)$ dan taraf nyata $\alpha=0,05$. Ternyata nilai $F_{\text {hitung }}=7,18>F_{\text {tabel }}=3,96$.

\section{REKOMENDASI}

Rekomendasi yang diberikan sehubungan dengan temuan penelitian sebagai beirkut: (1) Guru sebagai perancang pembelajaran disarankan memperhatikan karakteristik siswa dalam merancamg pembelajaran sehingga dengan demikian guru dapat menetapkan pilihan strategi pembelajaran yang lebih sesuai untuk dilaksanakan karena trategi pembelajaran dan karakteristik siswa merupakan suatu komponen yang dapat menentukan dan mempengaruhi hasil belajar, (2) Guru dalam kegiatan pembelajaran perlu menerapkan strategi pembelajaran kolaboratif dalam pembelajaran Akidah Akhlak, karena strategi pembelajaran kolaboratif memberikan hasil belajar yang lebih tinggi dalam mata pelajaran Akidah Akhlak dibandingkan dengan strategi pembelajaran kompetitif, dan (3) penelitian lain disarankan untuk peneliti lain agar menerapkan strategi pembelajaran kolaboratif dan pembelajaran kompetitif pada bidang studi lainnnya dan tidak hanya pada ranah kognitif saja,

\section{DAFTAR PUSTAKA}

Arikunto, Suharsimi. (2005) Dasar-Dasar Evaluasi Pendidikan. Jakarta: Bumi Aksara

Davies, Ivor K. (2001) The Management of Learning. Diterjemahkan ke dalam Bahasa Indonesia oleh Sudarsono Sudirjo dkk. Cetakan Kedua. Jakarta: Rajawali bekerjasama Dengan Pusat Antar Universitas di Universitas Terbuka. 
Davis, A. Colaborative Learning. http://www. wcer.wisc.edu/archie/ cli/cl/ doingclk/DCL1.asp. 1993.

Dewi S. Prawiradilaga, Raphael Rahardji dan Yusufhadi Miarso. Jakarta: Universitas Negeri Jakarta, 1994.

Dick, Walter dan Carey, Lou. (2005) The Systematic Design of Instruction. Fouth Edition. New York: Harper Collin College Publisher.

Dimyati dan Moedjiono. (1999) Belajar dan Pembelajaran, Jakarta: Rineka Cipta

Djamarah, Syaidul Bahri dan Zain, Ahmad. (2002) Strategi Belajar Mengajar. Jakarta: Rineka Cipta.

Gagne, Robert .M. dan Briggs, Lislee .J.. (1979) Principles of Instructional Design. New York: Holt Rinehart and Winston.

Gunawan, Adi. W. (2004) Genius Learning Strategi. Jakarta: Grasindo.

Hamalik, Oemar. (2004) Proses Belajar Mengajar. Jakarta: Bumi Aksara.

Hill, S. dan Hill, T. (1996) The Collaborative Classroom, A Guide to Cooperative Learning. Armadale Vic: Eleanor Curtain Publishing.

Johnson, D. W. dan Johnson, F.P. (1997) Joining Together, Group Theory and Group Skills. Boston: Allyn and Bacon.

Jonnasen, D.H.. (1996) Handbook of Research for Educational Communications and Technology. New York: MacMillan Library Reference USA.

Merril, M.D. (1981) Instructional Design Theory, New Jersey: Eagle Publicated.

Mudhoffir. (1993) Teknologi Instruksional. Bandung: Remaja Rosdakarya.

Nasution, S.(2000) Dikdaktik Asas-Asas Mengajar. Jakarta: Bumi Aksara.

Rohani, Ahmad dan Ahmadi, Abu. (2005) Pengelolaan Pengajaran. Jakarta: Rineka Cipta.

Romiszowski, A.J. (1981) Designing Instructional Systems, Decision Making in Course Planning and Curriculum Design. London: Kogan

Sagala, Syaiful. (2012) Konsep dan Makna Pembelajaran. Bandung: Alfabeta.

Sardiman A.M. (2011) Interaksi dan Motivasi Belajar Mengajar. Cetakan kedua. Jakarta: Raja Grafindo Persada.

Schmuck, R.A. dan Schmuck, P.A. (1980) Group Processes in the Classroom. Dubuque, Iowa: WM. C. Brown.

Seels, Barbara B dan Richey, Rita. C. Instructional Technology; The Definition And Domains of The Field. Washington: AECT, Alihbahasa:

Slavin, Robert E. (2004). Educational Psychology: Teory and Practice, Forth Edition. Boston: Allyn and Bacon. 